\title{
セメントの種類とコンクリートの破壊力学 特性值に関する実験的研究
}

\author{
二羽淳一郎 $1 \cdot$ 松尾豊史 $2 \cdot$ 岡本享久 $3 \cdot$ 田邊忠顕 4 \\ 1正会員 工博 アジア工科大学院助教授 構造工学科 (G.P.O. Box 2754, Bangkok 10501, Thailand) \\ 2正会貝 工修 電力中央研究所 構造部建設材料グループ（テ270-11千葉県我孫子市我孫子1646） \\ 3正会貝 工博 日本セメント中央研究所セメントコンクリート研究部（１35 東京都江東区清澄1-2-23） \\ 4 正会貝 工博 名古屋大学教授 工学部土木工学科（テ464 名古屋市千種区不老町）
}

本研究は, コンクリートの破壊力学特性值に及ほすセメントの種類の影響を, 骨材界面での「遷移帯」 の存在と結びつけて, 実験的に検討したものである. ビーライト系セメントを用いたコンクリートは, 材 齢初期の低強度時においても，破壊エネルギーが大きくなるが，これは骨材界面に脆弱な遷移帯がほとん ど存在しないことにより説明できると考えられる。一方，早強セメントを用いたコンクリートでは，遷移 帯の存在により, 材龄初期の破壊エネルギーが小さくなる。これらの実験的な知見を説明するため, 界面 強度と破壊エネルギーの関係について考察を行い, 現象を説明するための定性的な考え方を示した。

Key Words : transition zone, belite cement, high early cement, ordinary portland cement, fracture energy, tension softening curve, fracture mechanics

\section{1. 序論}

コンクリートのカ学特性を破壊力学のパラメータ により表現していく研究が随所で進められている。 これは最近の研究により,コンクリート構造物のひ び割れ発生から破壊に至る一連の現象が，コンク リート内部の微細ひび割れの発生, 凝集ならびに進 展過程により，説明できることが，広く認められる ようになってきたためと考えられる。ささらに，その ひび割れ進展過程をマクロ的にモデル化したパラ メータであり，また同時にコンクリートの材料特性 值とも考えることのできる破壊エネルギー $G_{F}$ と引張 軟化曲線を用いることにより，解析的にコンクリー 卜構造体強度の寸法依存性を表現できることも，破 壊力学的なアプローチが注目を集めてきている所以 である。

破壊エネルギー $G_{F}$ は, 単位面積の, 完全な, 引張 応力を全く伝達しないひび割れ面を形成するために 要するエネルギーと定義されている。この定義によ り，破壊エネルギーは，ママクロ的に捉えたひび割れ の発生以後, 言い換えれば引張強度到達以後, ひび 割れ面に作用する引張応力とひび割れ幅のマクロ的 な関係，すなわち引張軟化曲線によって囲まれる面
積として求められることになる。破壊エネルギー は, 引張軟化曲線とともに, コンクリートの破壊力 学における最も重要なパラメー夕であり, これが与 えられれば, コンクリート構造物のひび割れ進展過 程を数值解析的に評価していくことが可能となる.

一般には，破壊エネルギーはそれぞれのコンク リート固有の值, すなわち材料特性值として考えら れて抽り，各種の評価式が提案されている。ただ し，現行の設計規準でコンクリートの破壊エネル ギーを規定しているのはCEB-FIP Model Code 901)の みである。ここでは破壊エネルギーは, コンクリー トの圧縮強度と粗骨材最大寸法の関数として, 式(1) で与えられている。

$$
G_{F}=G_{F o}\left(\frac{f_{c}^{\prime}}{f_{c o}^{\prime}}\right)^{0.7}
$$

ただし， $G_{F}$ : 破壊エネルギー $(\mathrm{N} / \mathrm{mm}) ， G_{F o}$ :粗骨材 最大寸法に依存する破壊エネルギーの基本值, $f_{c}{ }^{\prime}$ : コンクリートの圧縮強度 $\left(\mathrm{N} / \mathrm{mm}^{2}\right), f_{c o}{ }^{\prime}: 10 \mathrm{~N} / \mathrm{mm}^{2}$ なお, 式(1)に取り入れられていない様々な要因の影 響のため, 式(1)による破壊エネルギーの予測精度が 低いことも，MC 90には述べられている。

破壊エネルギーが材料特性值と考えられながら， 
このような大きなバラッキを示す原因はどこにある のであろうか.

篠原らは，広範な実験に基づいて，破壊エネル ギーならびに引張軟化特性に及ぼす，切欠きはり試 験体のノッチ深さ, 載荷速度, コンクリートの粗骨 材最大寸法, 水セメント比, 養生方法, ならびに材 齢の影響を実験的に明らかにしている2)が，破壊工 ネルギーそのもののバラッキの大きさは，この実験 的研究からも明らかとなっている。

また，野村らはコンクリートの内部構造にさかの ぼって引張軟化特性について考察しているが，その 中でセメントペースト硬化体の水和進行の程度が, コンクリートの引張軟化特性に影響を及ほするとを 指摘している3)。これらの研究は非常に示唆に富む ものと言える。いずれにせよ，以上のことから類推 されるのは，たとえ破壤エネルギーを材料特性值と して扱うことができると仮定しても，これをコンク リートの圧縮強度や粗骨材最大寸法といったマクロ な尺度のみから評価したのでは, 推定精度が低くな るということ，さらに破壊エネルギーに対して精度 の高い予測を行うためには，セメント水和物レベル にさかのぼっての検討が必要であるということであ る.

これはコンクリート中の微細ひび割れが，骨材と モルタルとの界面の結合部分や，セメントペースト 硬化体内部での弱点部等から発生していくことを考 えれば，容易に予想できるところである。

しかしながら，現在までのところ，セメント水和 物レベルにまでさかのぼって，コンクリートの破壊 力学特性を論じた研究はほとんどない. 著者らは, ビーライト系セメントを用いたコンクリートの力学 特性について, 破壊力学的な検討を試みたのである が, その過程で, $\mathrm{C}_{2} \mathrm{~S}$ 含有量の多いビーライト系セ メントと $\mathrm{C}_{3} \mathrm{~S}$ 含有量の多い早強セメント，あるいは 普通セメントというセメントの種類が硬化コンク リートの破壊力学特性に大きな影響を与えることを 見出した4).

本研究は，これまでに得た実験的な知見を基に， なぜセメントの種類が硬化コンクリートの破壊力学 特性值に影響を与えるのかについて考察を行い, さ らにモルタルならびにコンクリートを用いた実験結 果に基づき，セメントの種類とコンクリートの破壊 力学特性值との関係を明らかにしていくものであ る。

\section{SEMによる硬化コンクリートの観察}

セメントクリンカー鉱物の内, $\mathrm{C}_{3} \mathrm{~S}$ と $\mathrm{C}_{2} \mathrm{~S}$ は水和 して, けい酸カルシウム水和物 (C-S-H) と水酸化

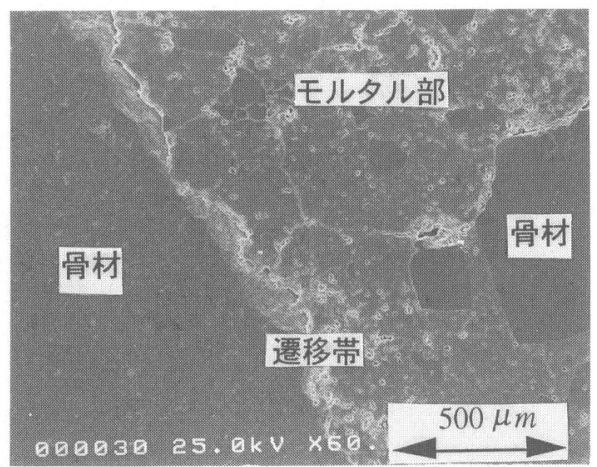

（a）早強セメントを用いたコンクリート

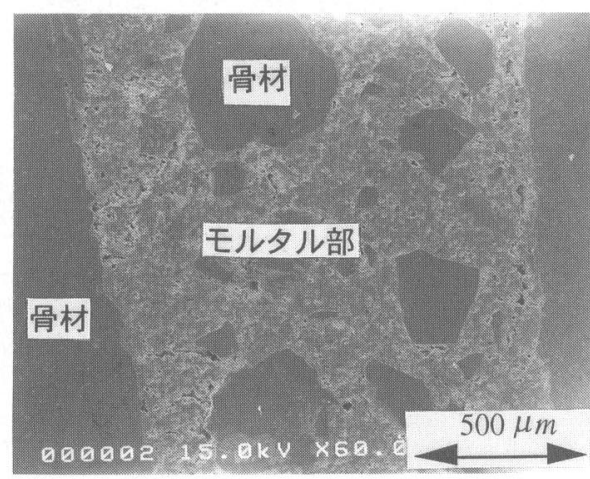

(b) ビーライト采セメントを用いたコンクリート

写真ー1 SEMによる骨材界面の観察

カルシウムを生成する。しかしながら，水酸化カル シウムの生成量は $\mathrm{C}_{2} \mathrm{~S}$ に比較して, $\mathrm{C}_{3} \mathrm{~S}$ の方が多 く，したがって，これを大量に含む早強セメントで は， $\mathrm{C}_{2} \mathrm{~S}$ に富むビーライト系セメントに比べて，生 成される水酸化カルシウム量が多いことになる。こ れらの水酸化カルシウムが, 骨材とセメントペース 卜界面に析出した場合，いわゆる「遷移帯」を形成 していく5)。水酸化カルシウムに富むこの遷移帯 は，比較的，疎な組織であり，他のセメントペース 卜部分とは不連続である。また，遷移帯の厚さは， 骨材が粗大化するほど，水セメント比が高くなるほ ど，単位水量が大きくなるほど，増加すると言われ ている5).

以上の知見は, セメント化学分野に扔ける研究の 成果であるが，骨材とモルタルとの界面からの微細 ひび割れの発生に着目する破壊力学の視点に立って も，無視できない情報である，すなわち，骨材界面 の脆弱な薄膜層である遷移帯の生成量の少ないビー ライト系セメントを用いたコンクリート6)は，相対 的に遷移带生成量の多い早強セメントを用いたコン クリートよりも, 破壊力学特性に優れるという仮説 が成り立つのである. 
表-1 使用材料の物性

\begin{tabular}{|c|c|c|c|}
\hline 材料種別 & 出所 & 比重 & その他 \\
\hline $\begin{array}{c}\text { 早強 } \\
\text { セメント }\end{array}$ & $\mathrm{N}$ 社製 & 3.14 & $\begin{array}{c}\mathrm{C}_{2} \mathrm{~S}=9.3 \%, \mathrm{C}_{3} \mathrm{~S}=65.2 \%, \\
\text { 比表面積 }=4450 \mathrm{~cm} 2 / \mathrm{g}\end{array}$ \\
\hline $\begin{array}{c}\text { 普通 } \\
\text { セメント }\end{array}$ & $\mathrm{N}$ 社製 & 3.16 & $\begin{array}{c}\mathrm{C}_{2} \mathrm{~S}=28.7 \%, \mathrm{C}_{3} \mathrm{~S}=45.5 \%, \\
\text { 比表面積 }=3210 \mathrm{~cm} 2 / \mathrm{g}\end{array}$ \\
\hline $\begin{array}{c}\text { ビーライト } \\
\text { 系セメント }\end{array}$ & $\mathrm{N}$ 社製 & 3.22 & $\begin{array}{c}\mathrm{C}_{2} \mathrm{~S}=58.6 \%, \mathrm{C}_{3} \mathrm{~S}=23.0 \%, \\
\text { 比表面積 }=3360 \mathrm{~cm} 2 / \mathrm{g}\end{array}$ \\
\hline $\begin{array}{c}\text { 細骨材 } \\
\text { 粗骨材 }\end{array}$ & $\begin{array}{c}\text { 豊田産 } \\
\text { 山砂 }\end{array}$ & 2.51 & $\mathrm{FM}=2.80$, 吸水率=1.47\% \\
\hline $\begin{array}{c}\text { 産砕石 } \\
\text { 高性能 }\end{array}$ & 2.62 & $\mathrm{FM}=6.62$, 吸水率 $=0.86 \%$ \\
$\mathrm{AE}$ 減水剤 & $\mathrm{T}$ 社製 & - & ポリカルボン酸系 \\
\hline
\end{tabular}

表ー2 コンクリートの配合 (SEM観察)

\begin{tabular}{|c|c|c|c|c|c|c|c|c|}
\hline \multirow{2}{*}{$\begin{array}{l}\text { 骨材 } \\
\text { 最大 } \\
\text { 寸法 } \\
\mathrm{mm}\end{array}$} & \multirow{2}{*}{$\begin{array}{l}\text { セx } \\
\text { ント } \\
\text { 種別 }\end{array}$} & \multirow{2}{*}{$\begin{array}{c}\text { W/C } \\
\%\end{array}$} & \multirow{2}{*}{$\begin{array}{l}\text { s/a } \\
\%\end{array}$} & \multicolumn{5}{|c|}{ 単位量(kg/m³) } \\
\hline & & & & W & $\mathrm{C}$ & $\mathrm{s}$ & G & $\begin{array}{l}\mathrm{AE} \text { 剂 } \\
\mathrm{C} \times \%\end{array}$ \\
\hline 13 & 早強 & 45 & 49.5 & 171 & 381 & 838 & 896 & 0.6 \\
\hline 13 & $\begin{array}{l}\text { ビー } \\
\text { ライ } \\
\text { ト系 }\end{array}$ & 45 & 49.5 & 173 & 385 & 838 & 896 & 1.2 \\
\hline
\end{tabular}

写真-1(a)(b)は，走査型電子顕微鏡（SEM）によ る, 硬化コンクリートの骨材界面の観察結果の一例 である。(a)は早強セメントを用いたコンクリー ト，(b)はビーライト系セメントを用いたコンク リートである。いずれの場合も，W/C=45\%であ る。実験に使用した材料の物性值を表ー1に，コン クリートの配合を表一2に示す。

写真一1(a)において，骨材とモルタルの界面に観 察される色の淡い部分（相対的に白い部分）が遷移 帯（水酸化カルシウム層）である. 早強セメントを 用いたコンクリートでは，この存在が明確に認めら れるのに対して, 写真ー1(b)のビーライト系セメン トを用いたコンクリートでは，これがほとんど認め られない。これは, 羽原5), 内川6)の研究成果とも 一致している.

ここに示した写真ー1 (a)(b)は，SEMによる骨材界 面の観測結果の一例であるが，先に述べたセメント の種類と遷移帯生成量の関係から考えても，ビーラ イト系セメントを用いたコンクリートでは，骨材界 面の破壊力学特性が, 早強セメントを用いたコンク リートよりも改善されているのではないかと考えら れるのである。

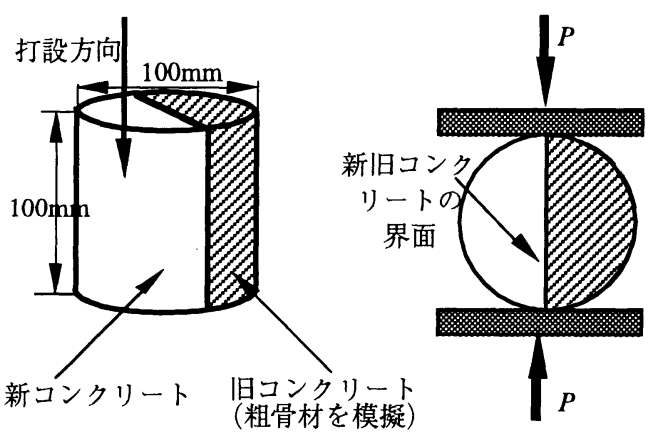

図ー1 付着特性評価のための試験体と載荷方法

\section{3 、割裂試験を用いた骨材界面の付着特性の評 価}

\section{（1）骨材界面の付着特性}

骨材界面の付着特性には，そこでの遷移帯生成量 が大きく関係すると考えられる．2．における考察 によれば，ビーライト系セメントを用いたコンク リートの骨材界面の付着特性の方が, 早強セメント を用いたコンクリートよりも優れていると予想され るが，このことを直接的に実証するには，骨材界面 の付着強度そのものを調べればよい.

しかしながら, 骨材界面の付着強度を評価する試 験法は, 現在までのところ確立されていない。著者 らは，骨材界面の付着強度を測定するため，骨材と モルタルをシリアルに配置して意図的に付着させた 供試体を作成し，直接引張試験を試みたのである が, 実験操作が困難で, しかもデータのバラツキが 相当に大きかった，そこで，このような供試体を用 いた直接引張試験は, 骨材界面の付着強度の評価に は不適当であると判断した。

試験操作が簡単で試験結果のバラツキが少ないこ と，また測定に特殊な治具を要しないこと等を考え あわせ，直接引張試験に代わるものとして，以下に 示すような，割裂試験法による界面の引張試験によ り，付着特性を評価することとした。

\section{（2）割裂試験による界面の付着特性評価}

圧縮強度 $1000 \mathrm{kgf} / \mathrm{cm}^{2}$ クラスの高強度コンクリート で直径 $10 \mathrm{~cm}$, 高さ $10 \mathrm{~cm}$ の円柱供試体を作成する. 所定の高強度が得られた後，これをコンクリート切 断機で半分に切断する。 この高強度コンクリートは 粗骨材を模したものである。図ー1に示すように， 切断された高強度コンクリートの半円柱体を型枠内 にセットし，残り部分に，新コンクリートを打設す る.このようにして円柱体の直径に沿った付着面を 得る. この付着面は, 切断機による切断面であるた 
表－3 高強度コンクリート用使用材料の物性

\begin{tabular}{|c|c|c|}
\hline 材料種別 & 出所 & 比重 \\
\hline ビーライト系セメント & C社製 & 3.22 \\
\hline シリカフューム $(\mathrm{SF})$ & E社製 & 2.21 \\
\hline 細骨材 & 大井川産川砂 & 2.63 \\
\hline 粗骨材 & 段戸山産砕石 & 2.61 \\
\hline 高性能AE減水剤(SP) & T社製 & - \\
\hline
\end{tabular}

表 -4 高強度コンクリートの配合

\begin{tabular}{|c|c|c|c|c|c|c|c|c|}
\hline \multirow{2}{*}{$\begin{array}{l}\text { 骨材 } \\
\text { 最大 } \\
\text { 寸法 } \\
\mathrm{mm}\end{array}$} & \multirow{2}{*}{$\begin{array}{l}\text { セx } \\
\text { ント } \\
\text { 種別 }\end{array}$} & \multirow{2}{*}{$\begin{array}{c}\mathrm{W} / \\
(\mathrm{C}+\mathrm{SF}) \\
\%\end{array}$} & \multicolumn{6}{|c|}{ 単位量 $\left(\mathrm{kg} / \mathrm{m}^{3}\right)$} \\
\hline & & & W & $\mathrm{C}$ & SF & $S$ & G & SP \\
\hline 15 & $\begin{array}{l}\text { ビー } \\
\text { ライ } \\
\text { ト系 }\end{array}$ & 15 & 90 & 522 & 78 & 631 & 1164 & 18 \\
\hline
\end{tabular}

表－5 コンクリートの配合（付着特性評価用）

\begin{tabular}{|c|c|c|c|c|c|c|c|c|}
\hline \multirow{2}{*}{$\begin{array}{l}\text { 骨材 } \\
\text { 最大 } \\
\text { 寸法 } \\
\mathrm{mm}\end{array}$} & \multirow{2}{*}{$\begin{array}{l}\text { セメ } \\
\text { ント } \\
\text { 種別 }\end{array}$} & \multirow{2}{*}{$\begin{array}{c}\text { W/C } \\
\%\end{array}$} & \multirow{2}{*}{$\begin{array}{c}\text { s/a } \\
\%\end{array}$} & \multicolumn{5}{|c|}{ 単位量 $\left(\mathrm{kg} / \mathrm{m}^{3}\right)$} \\
\hline & & & & W & $\mathrm{C}$ & $S$ & G & $\begin{array}{l}\mathrm{AE} \lambda^{\prime} \\
\mathrm{C} \times \%\end{array}$ \\
\hline \multirow{2}{*}{13} & \multirow{2}{*}{ 早強 } & 65 & 53.5 & 172 & 264 & 955 & 870 & \multirow{2}{*}{0.6} \\
\hline & & 45 & 49.5 & 171 & 381 & 838 & 896 & \\
\hline \multirow{2}{*}{13} & \multirow{2}{*}{$\begin{array}{l}\text { ビー } \\
\text { ライ } \\
\text { ト系 }\end{array}$} & 65 & 53.5 & 173 & 266 & 955 & 870 & \multirow{2}{*}{1.2} \\
\hline & & 45 & 49.5 & 173 & 385 & 838 & 896 & \\
\hline
\end{tabular}

め, 骨材表面とは異なって, 滑らかなものとなって いる. また，この高強度コンクリートの切断面には 骨材部とモルタル部が混在しており，粗骨材そのも のでないことは明らかである。

しかしながら，ここでの実験の趣旨は，七メント の種類が，界面でのコンクリート付着特性にどのよ うな変化を及ぼすかを評価することにある，高強度 コンクリートを用いて模擬的な界面を作り出し, こ の界面の付着を意図的に破壊することにより，七メ ントの種類による付着特性変化の相対比較が可能で あると考えたのである。

この付着面が上下方向となるように供試体を試験 機に据え付け, 割裂試験により, 引張強度を测定し た。そして，これにより界面の付着特性を評価する こととした.

\section{（3）実験ならびに考察}

付着特性評価のためのコンクリート（新コンク
表ー6 付着特性に関する実験結果

\begin{tabular}{|c|c|c|c|c|c|}
\hline \multirow{2}{*}{$\begin{array}{c}\text { セメント } \\
\text { 種別 }\end{array}$} & \multirow{2}{*}{$\begin{array}{c}\mathrm{W} / \mathrm{C} \\
\%\end{array}$} & \multicolumn{2}{|c|}{$\begin{array}{c}\text { 界面の } \\
\text { 引張強度 } \\
\mathrm{kgf} / \mathrm{cm}^{2}\end{array}$} & \multicolumn{2}{|c|}{$\begin{array}{c}\text { コンクリート } \\
\text { の圧縮強度 } \\
\mathrm{kgf} / \mathrm{cm}^{2}\end{array}$} \\
\hline & & $\begin{array}{l}\text { 材齢 } \\
7 \text { 日 }\end{array}$ & $\begin{array}{l}\text { 材齢 } \\
28 \text { 日 }\end{array}$ & $\begin{array}{l}\text { 材齢 } \\
7 \text { 日 }\end{array}$ & $\begin{array}{l}\text { 材齢 } \\
28 \text { 日 }\end{array}$ \\
\hline \multirow{2}{*}{$\begin{array}{c}\text { 早強 } \\
\text { セメント }\end{array}$} & 65 & 6.9 & 12.8 & 235 & 263 \\
\hline & 45 & 11.0 & 13.2 & 356 & 428 \\
\hline \multirow{2}{*}{$\begin{array}{l}\text { ビーライト } \\
\text { 系セメント }\end{array}$} & 65 & 11.8 & 12.9 & 165 & 310 \\
\hline & 45 & 12.7 & 13.1 & 196 & 506 \\
\hline
\end{tabular}

界面の引張強度 $\left(\mathrm{kgf} / \mathrm{cm}^{2}\right)$

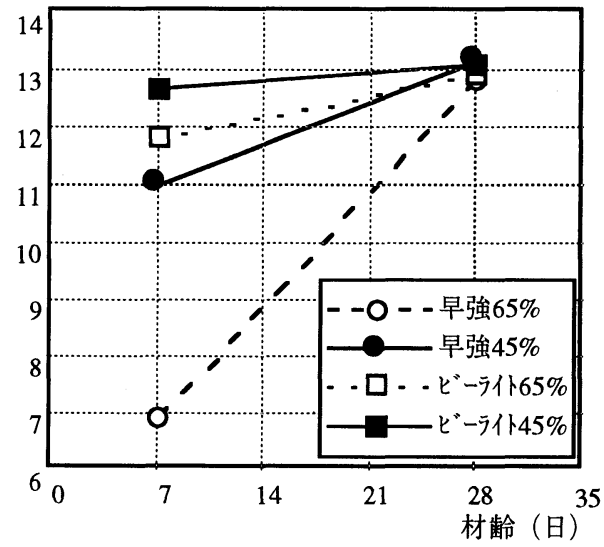

図－2 材齢に伴う界面の引張強度の変化

リート）に使用した材料の物性值は表ー1に示した 通りである。また，その配合を表ー5に示した。一 方, 高強度コンクリート（旧コンクリート）用使用 材料の物性とその配合をそれぞれ表 -3 ，表 -4 に示 した。

高強度コンクリートではさらにオートクレーブ養 生を行った。試験時（材㱓4週以上）における高強 度コンクリートの圧縮強度は平均で $1930 \mathrm{kgf} / \mathrm{cm}^{2}$ で あった。

付着特性評価のための供試体は, 新コンクリート 打設後，1日で脱型し，その後は試験前日まで, 水 中養生した。なお，実験の結果，割裂によるひび割 れは，すべて新旧コンクリートの界面に発生するこ とが確認された。

表ー6および図ー2に実験結果を示す。

材齡7日における実験結果から，ビーライト系セ メントを用いたコンクリートは，早強セメントを用 いたコンクリートよりも, 界面の引張強度が高く, 界面の付着特性が良好であることが認められた。こ れに対して早強セメントを用いたコンクリートで は, 特に水セメント比 $65 \%$ の場合, 界面の引張強度 
はかなり小さいものとなっており，付着特性に劣る ことを示している．材齢7日，水セメント比 $65 \%$ の 早強セメントを用いたコンクリートの圧縮強度は, ビーライト系セメントを用いた対応するコンクリー トよりも約 $40 \%$ 大きいのであるが, 界面の付着強度 は，逆に約40\%減となっているのである。 なお，水 セメント比 $45 \%$ の場合は, 引張強度はあまりビーラ イト系とは異ならないものの，わずかにこれを下 回っている.

材齢28日になると，七メントの種類による界面の 引張強度の差は，いずれの場合においてもほとんど 見られなくなった。この時点では，ビーライト系セ メントを用いたコンクリートの圧縮強度の方が，早 強セメントを用いたコンクリートを上回っているの であるが，界面の引張強度は，これとは無関係にほ ほ一定となっている.

以上の結果を総括すれば，ビーライト系セメント を用いたコンクリートと比較した場合, 早強セメン トを用いたコンクリートでは, 特に水セメント比の 大きい場合，材齢7日程度の初期材齢時において, 骨材界面の付着特性に劣ると判断される。またこの 付着特性が, 経時変化していくことも明らかであ る.ささらに, この付着特性変化のメカニズムは圧縮 強度の発現とは無関係のようである。

セメント化学の分野における研究によれば，骨材 界面の遷移帯の厚さは経時変化し, 材齢7日で最大 となり，それ以後は，徐々に減少していくと言われ ている5），6）。たたし，本試験における界面の付 着特性の変化を, 遷移帯の存在のみに帰着させて説 明することは現状では困難である。しかしながら， 早強セメントを用いたコンクリートならびにビーラ イト系セメントを用いたコンクリートにおいて，遷 移帯を含む水和生成物の相違がこれらの界面の付着 特性に大きく影響していることは明らかである。 そ して, 遷移帯の存在はその中でも重要な部分を占め ていると考えられるのである。

\section{4. モルタル供試体を用いた破壊力学特性值の 計測}

\section{（1）実験の概要}

遷移帯の生成厚さは骨材径の粗大化とともに増加 していくと言われている。 そこで，この点について 検討するため, 最大径の異なる細骨材を用いて供試 体を作成し，硬化モルタルの破壊力学特性値を計測 し，セメントの種類が破壊力学特性值に及ぼす影響 について考察することとした，細骨材は，粒径に よってふるい分けして2種類用意した．便宜上，こ れを粗砂と細砂と呼ぶこととする（表一7参照）.
表-7 モルタル供試体の概要

\begin{tabular}{|c|c|c|c|c|}
\hline $\begin{array}{c}\text { セメント } \\
\text { 種別 }\end{array}$ & \multicolumn{2}{|c|}{ 早強セメント } & \multicolumn{2}{|c|}{$\begin{array}{c}\text { ビーライト系 } \\
\text { セメント }\end{array}$} \\
\hline $\mathrm{W} / \mathrm{C}(\%)$ & \multicolumn{2}{|c|}{50} & \multicolumn{2}{|c|}{50} \\
\hline$C: S$ & \multicolumn{2}{|c|}{$1: 3$} & \multicolumn{2}{|c|}{$1: 3$} \\
\hline $\begin{array}{l}\text { 細骨材の } \\
\text { 粒径(mm) }\end{array}$ & $\begin{array}{c}0.85 \\
\sim 1.19 \\
\text { (細砂) }\end{array}$ & $\begin{array}{c}1.19 \\
\sim 2.38 \\
\text { (粗砂) }\end{array}$ & $\begin{array}{c}0.85 \\
\sim 1.19 \\
\text { (細砂) }\end{array}$ & $\begin{array}{c}1.19 \\
\sim 2.38 \\
\text { (粗砂) }\end{array}$ \\
\hline
\end{tabular}

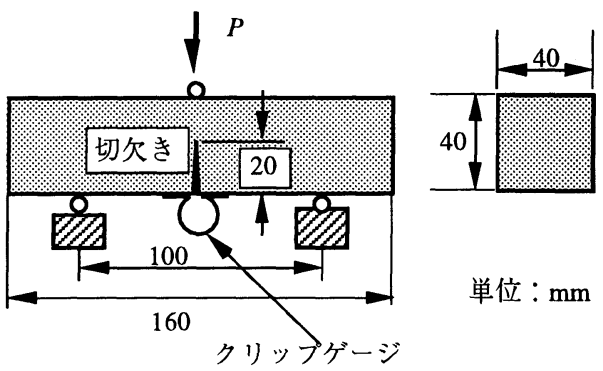

図ー3 切欠きはりの3点曲げ試験（モルタル）

実験は, 図ー3に示す, 切欠きはりの3点曲げ試験 により行った。供試体の断面は $4 \times 4 \mathrm{~cm}$, 長さは $16 \mathrm{~cm}$ ，単純支持された載荷スパンは $10 \mathrm{~cm}$ である. スパン中央の載荷点直下には，ひび割れが局所化す るように，あらかじめ高さ $2 \mathrm{~cm}$ の切欠きを設けてあ る. 切欠きは, 載荷試験の直前に岩石用のダイヤモ ンドカッターを用いて設けたものである。

荷重一変位関係に加えて,ひび割れ幅の開口変位 も測定した．なお，試験時の材齢はいずれも28日で ある。

\section{（2）実験結果}

RILEMの方法に準じ，式(2)により，破壊エネル ギー $G_{F}$ を求める.

$$
G_{F}=\frac{W_{o}+m \cdot \delta_{o}}{A_{l i g}}
$$

ただし， $W_{o}$ : 荷重一変位曲線下の面積

$m$ : 支点間の供試体重量

$\delta_{o}:$ はり破断時の変位

$A_{\text {lig }}$ : 切欠き上のはりの破断部分面積（リ ガメント面積）ではり軸に垂直な平 面に投影した面積

一般に引張強度あるいは圧縮強度が大きくなるほ ど，破壊エネルギーは大きくなる。したがって，引 張強度や圧縮強度が相当に違うレベルで, 破壊エネ ルギーの絶対値そのものを比較することは適当では 
表-8 材龄28日のモルタルの破壊エネルギーと $A_{o}$

\begin{tabular}{|c|c|c|c|c|c|}
\hline $\begin{array}{c}\text { セメント } \\
\text { 種別 }\end{array}$ & $\begin{array}{l}\text { 骨材 } \\
\text { 種類 }\end{array}$ & $\begin{array}{c}\text { 圧縮強度 } \\
\mathrm{kgf} / \mathrm{cm}^{2}\end{array}$ & $\underset{\mathrm{kgf} / \mathrm{cm}}{G_{F}}$ & \multicolumn{2}{|c|}{$\begin{array}{l}\text { 定数 } A_{o} \\
\times 10^{-3}\end{array}$} \\
\hline \multirow{2}{*}{$\begin{array}{c}\text { 早強 } \\
\text { セメント }\end{array}$} & 細砂 & 447 & 0.0562 & 0.785 & \multirow{2}{*}{$\begin{array}{l}\text { 平均 } \\
0.685\end{array}$} \\
\hline & 粗砂 & 458 & 0.0426 & 0.580 & \\
\hline \multirow{2}{*}{$\begin{array}{l}\text { ビーライト } \\
\text { 系セメント }\end{array}$} & 細砂 & 216 & 0.0280 & 0.650 & \multirow{2}{*}{$\begin{array}{l}\text { 平均 } \\
0.720\end{array}$} \\
\hline & 粗砂 & 249 & 0.0375 & 0.790 & \\
\hline
\end{tabular}

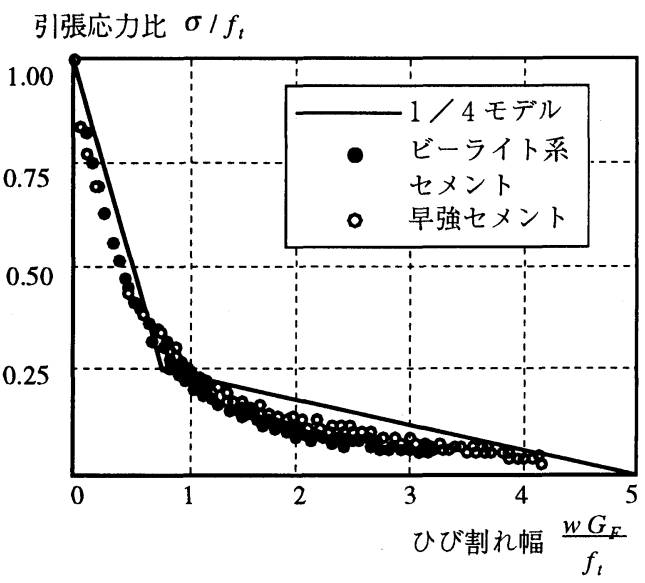

図ー4 モルタルの引張軟化曲線 (細砂)

ないと考えられる。そこで, CEB-FIP Model Code 90のコンクリートの破壊エネルギーの評価式（式 (1)）を参考にして，実測されたモルタルの破壊エネ ルギーをモルタルの圧縮強度の0.7乗で補正した定 数 $A_{o}$ (式 (3)）についても検討してみることとし た。

$$
A_{o}=\frac{G_{F}}{f_{c}{ }^{10.7}}
$$

さらに，内田らの提案した新J積分法7)を用いれ ば，計測された荷重一変位関係，および荷重一ひび 割れ幅関係より，引張軟化曲線を求めることができ る。硬化モルタルについて, 得られた実験結果を表 ー8ならびに図ー4に示す。

\section{（3）破壊力学特性值に関する考察}

表ー8によれば，材齢28日に扔ける破壊エネル ギーの值は，早強セメントを用いたモルタルの方 が, ビーライト系セメントを用いたモルタルよりも 大きかった。ただし，細骨材の粒径と破壊エネル ギーの間には明確な関係は認められなかった。

ここで，ビーライト系セメントを用いたモルタル の強度発現の程度を考慮し, 式(3)により圧縮強度

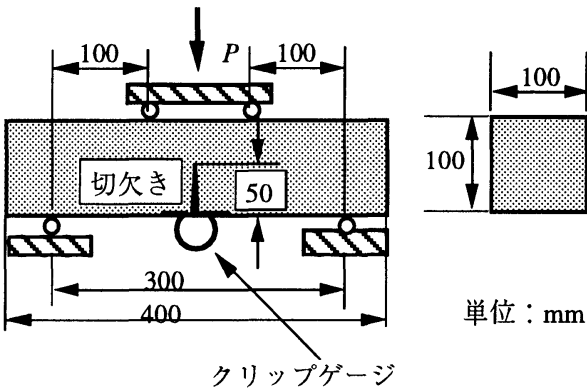

図－5 切欠きはりの3等分点載荷試験（コンクリート）

による補正を行い, 定数 $A_{o}$ による比較を行ってみ た.

これによれば，表ー8に示す通り，粗砂の場合に はビーライト系セメントを用いたモルタルのA $A_{o}$ が大 きく, 細砂の場合は少し小さくなる程度であった。 また，平均的には，ビーライト系セメントを用いた モルタルの方が大きかった.

すなわち，ビーライト系セメントを用いたモル夕 ルの破壊エネルギーは, 強度発現の影響を考慮し， 圧縮強度による補正を行えば，早強セメントを用い たモルタルの場合と同程度以上となるのである。

この結果は，2.で述べた遷移帯の存在と破壊工 ネルギーに関する定性的な関係と同様の傾向である と言える，ただし，前述の通り，細骨材の粒径と遷 移帯の影響については，明確な関係は得られず，こ の程度の粒径の差では，遷移帯の存在に及ほすす影響 は比較的小さいのではないかと考えられる。

なお，図一4は細砂を用いたモル夕ルの引張軟化 曲線の実測結果を $1 / 4$ モデルとともに示したもの である。モルタルの引張軟化曲線は, セメントの種 類に関係なく，1／4 モデルと良い一致を示してい ることがわかる。

なお, 折れ曲がり点以降, 1/4 モデルは実験結 果を多少大きめに評価しているが，これは，実験に おいて，想定した破壊断面位置（=切欠き断面位 置) 以外での微細ひび割れの発生によるエネルギー 吸収があったためと考えられる。しかしながら，そ の相違はわずかであって，1／4 モデルは，コンク リート同様，モルタルの引張軟化曲線としても十分 に適用可能であると判断される。

\section{5.コンクリート供試体による破壊エネルギー の計測}

\section{(1) 実験の概要}

モルタルの場合は, 圧縮強度による補正を行うこ とにより, セメントの種類が破壊エネルギーに及ほ す影響を確認することができた。ここでは，モル夕 
表－9 コンクリートの配合

\begin{tabular}{|c|c|c|c|c|c|c|c|c|}
\hline \multirow{2}{*}{$\begin{array}{l}\text { 骨材 } \\
\text { 最大 } \\
\text { 寸法 } \\
\text { mm }\end{array}$} & \multirow{2}{*}{$\begin{array}{l}\text { セメ } \\
\text { ント } \\
\text { 種別 }\end{array}$} & \multirow{2}{*}{$\begin{array}{c}\text { W/C } \\
\%\end{array}$} & \multirow{2}{*}{$\begin{array}{l}\text { s/a } \\
\%\end{array}$} & \multicolumn{5}{|c|}{ 単位量 $\left(\mathrm{kg} / \mathrm{m}^{3}\right)$} \\
\hline & & & & W & $\mathrm{C}$ & $S$ & $\mathrm{G}$ & $\begin{array}{l}\mathrm{AE} \text { 剤 } \\
\mathrm{C} \times \%\end{array}$ \\
\hline \multirow{2}{*}{13} & \multirow{2}{*}{ 早強 } & 55 & 51.5 & 172 & 312 & 900 & 888 & \multirow{2}{*}{1.2} \\
\hline & & 45 & 49.5 & 171 & 381 & 838 & 896 & \\
\hline \multirow{2}{*}{13} & \multirow{2}{*}{ 普通 } & 55 & 51.5 & 172 & 313 & 900 & 888 & \multirow{2}{*}{0.8} \\
\hline & & 45 & 49.5 & 172 & 382 & 838 & 896 & \\
\hline \multirow{2}{*}{13} & \multirow{2}{*}{$\begin{array}{l}\text { ビー } \\
\text { ライ } \\
\text { ト系 }\end{array}$} & 55 & 51.5 & 173 & 315 & 955 & 888 & \multirow{2}{*}{0.6} \\
\hline & & 45 & 49.5 & 173 & 385 & 838 & 896 & \\
\hline
\end{tabular}

破壊エネルギー $G_{F}(\mathrm{kgf} / \mathrm{cm})$

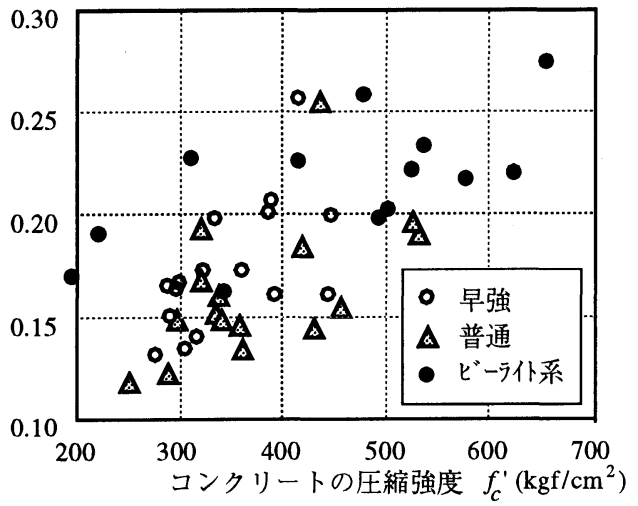

(a) $G_{F}-f_{c}^{\prime}$ 関係

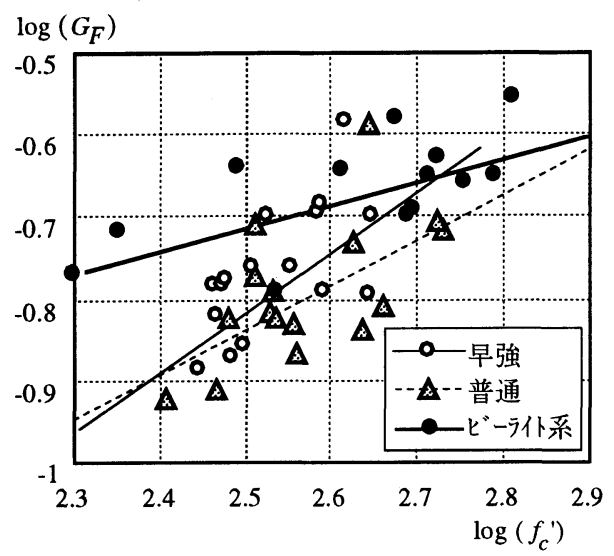

(b) $\log \left(G_{F}\right)-\log \left(f_{c}\right)$ 関係

図-6 圧縮強度と破壊エネルギーの関係

ルに続いて, 硬化コンクリートの破壊エネルギーを 計測し，セメントの種類がこれに及ほす影響を実験 的に明らかにすることとした。実験は図ー5に示 す, 切欠きはりの3等分点曲げ試験により行った.
供試体の断面は, $10 \times 10 \mathrm{~cm}$, 長さは $40 \mathrm{~cm}$, 載荷ス パンは $30 \mathrm{~cm}$ であ。載荷点直下にはコンクリート 用カッターにより，高さ $5 \mathrm{~cm}$ の切欠きを設けた.

表-9に示す配合で, セメントの種類 (早強, 普 通, ビーライト系），水セメント比を変化させたコ ンクリート供試体を作成し，材㱓7日，28日，91日 で曲げ試験を行い, 荷重一変位関係, 荷重一ひび割 れ幅関係を計測した。なお，コンクリートの使用材 料は表ー 1 に示すものと同一である. また粗骨材の 最大寸法は $13 \mathrm{~mm}$ ですべて一定である.

\section{(2) 実験結果}

図ー6(a)(b)は計測された破壊エネルギーとコンク リートの圧縮強度の関係を示したものであり，(a) は通常表示, (b)は両対数表示である.コンクリー トの破壊エネルギーがコンクリートの圧縮強度の関 数として表され，CEB-FIP Model Code 90のように， 例えば指数関数で表示できるものとすれば，両対数 表示された場合, 各セメントを用いて作成されたコ ンクリートに対する回帰直線の勾配は一致するはず である、ところが, 図一6(b)に示された実験結果と 回帰直線を見れば，普通セメント，早強セメントに 比較して，ビーライト系セメントを用いたコンク リートの破壊エネルギーに対する回帰直線の勾配は 緩やかであることがわかる。

図ー6(b)に示されるように，材齢の進行に伴う圧 縮強度の発現により, セメントの種類がコンクリー トの破壊エネルギーの大きさに及ぼす影響には，次 第に違いが認められなくなっていく．しかしなが ら, 材齡初期の低強度時において, ビーライト系セ メントを用いたコンクリートの破壊エネルギーは, 早強セメントあるいは普通セメントを用いたコンク リートよりも明らかに大きいのである。

なお，回帰直線の勾配が緩やかであることからわ かるように，ビーライト系セメントを用いたコンク リートの, 圧縮強度に伴う破壊エネルギーの増加 は，材龄の進行とともに次第に小さくなる傾向にあ る、ただし、ビーライト系セメントは長期の強度発 現性に優れているので，他のセメントを用いた場合 よりも，破壊エネルギーは常に大きい傾向にある.

図一7(a)(b)は，切欠きはりの曲げ試験から得られ た荷重一ひび割れ幅関係である。(a)に示す, 早強 セメントを用いたコンクリートの場合, 荷重一ひび 割れ幅関係は，材㱓とともに相似的に拡大していく 様子が認められる。一方，(b)のビーライト系セメ ントを用いたコンクリートの場合は，材龄初期の曲 線のテール部がひび割れ幅の増加にもかかわらず, あまり急激に減少せず，長期材嚙の曲線と交差して おり，破壊エネルギーが大きいことを表している。 
荷重 $P(\mathrm{kgf})$

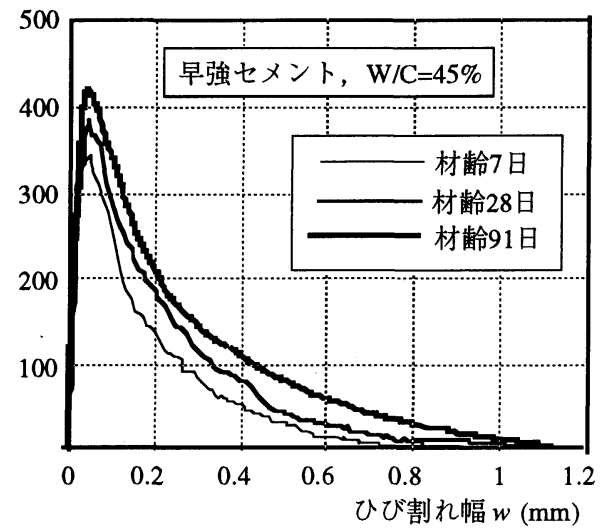

（a）早強セメントを用いたコンクリートはりの 荷重一ひび割れ幅関係の経時変化

荷重 $P(\mathrm{kgf})$

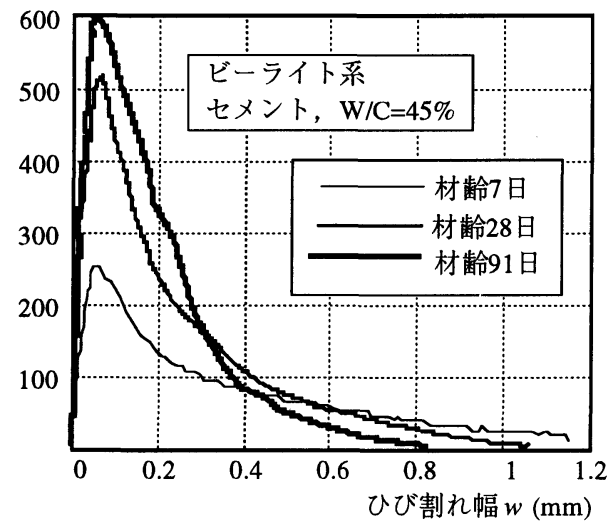

(b) ビーライト系セメントを用いたコンクリートはりの 荷重一ひび割れ幅関係の経時変化

図ー7 実測された引張軟化曲線

曲げ強度 $f_{b}\left(\mathrm{kgf} / \mathrm{cm}^{2}\right)$

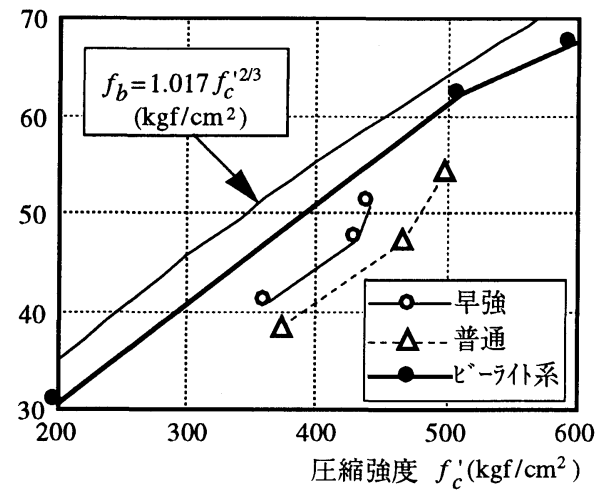

図-8 圧縮強度と曲げ強度との関係
このように，材齢初期での破壊エネルギーの大きい ことが，ビーライト系セメントを用いたコンクリー トの特徴である。

\section{（3）コンクリートの曲げ強度}

コンクリートの破壊エネルギーが大きくなるとい うことは, 引張軟化特性の影響を受ける曲げ強度, あるいは，鉄筋コンクリート部材としての斜め引張 破壊強度が高くなることを意味している。

図ー8はW/C $=0.45$ の場合の各セメントを用いたコ ンクリートの圧縮強度と曲げ強度の関係を示したも のである. 図中には参考のため, $f_{b}=1.017 f_{c}{ }^{2 / 3}$ と して求めた，曲げ強度の予測値も示してある。

予想される通りビーライト系セメントを用いたコ ンクリートの曲げ強度は, 他のセメントを用いたコ ンクリートよりも, 同一の圧縮強度に対して, 常に 大きくなっており，ビーライト系セメントを用いた コンクリートの破壊エネルギーの大きさを裏付けて いる．また，これが最も予測式に近い曲げ強度を示 している。

\section{6. 界面強度と破壊エネルギーに関する考察}

コンクリートの破壊エネルギーの大小は，コンク リートの圧縮強度や粗骨材最大寸法といったマクロ な尺度の他に，骨材とモルタルとの界面の付着特性 にも影響されることが，七メントの種類を変化させ た実験の結果, 明らかとなった。ここでは, この界 面の強度とコンクリートの破壊エネルギーの関係に ついて考察する。

通常の場合, コンクリートの微細ひび割れは強度 的な弱点部である骨材とモルタルの界面，あるいは モルタル内部の欠陥部等から発生していく，骨材界 面に発生するひび割れは，一般にボンドひび割れと 呼ばれている。これらの微細ひび割れは, 成長して マトリクスひび割れを形成し，さらに伝播してい く.この過程で, マトリクスひび割れが骨材と交差 すると，その際の条件に応じて，ひび割れが骨材を 迁回するか，貫通するかが決まる。

ここで，骨材界面の強度は，コンクリート自体の 強度に加えて, 界面に析出する遷移帯の生成量に関 係すると仮定する。一方, モルタル部の強度には遷 移帯生成量の影響は小さいと仮定する。これにさら に骨材自体の強度を加え，コンクリートの水セメン 卜比に対して概念的に示したのが，図ー9である。

図ー9において, 領域Aはモルタル部の強度に支配 される領域, Bは界面強度が支配的な領域, Cは骨 材強度が支配的な領域を示している。強度的には, $\mathrm{A}$ が最も弱く, B, Cの順である。しかしながら, 領 


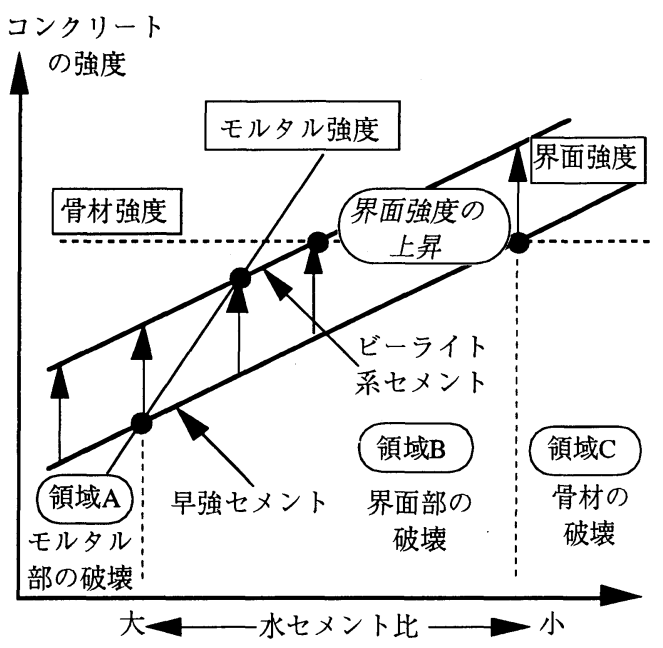

図ー9 界面強度と破壊モードとの関係

域Aでは,ひび割れがモルタル部に多数発生し，さ らにこれらのひび割れは骨材を迂回していくので, コンクリート単位体積当たりに吸収される破壊エネ ルギーは大きく，またこの領域が低強度であること を考えると，強度当たりの破壊エネルギーは相対的 にさらに大きくなる。

逆に領域Cでは，ひび割れが分散せず局所化し， しかも形状的には骨材を貫通した直線型のひび割れ となるので，吸収される破壊エネルギーは小さくな り,さらにこの領域が高強度域であることにより， 強度当たりの破壊エネルギーは小さくなる。領域 $\mathrm{B}$ はこの中間である. 結局, 強度当たりの破壊エネル ギーはAが最も大きく，以下， B， Cの順となると考 えられる。

ビーライト系セメントを用いたコンクリートで は，骨材界面での遷移帯生成量がごくわずかであ り，したがって界面強度は高いと考えられる。この ため，図一9に示されるように，界面強度線が上昇 して領域 Bの範囲が狭まり, 特に材齢初期の低強度 時の挙動は領域Aに支配されることになる。この結 果, 強度当たりの破壊エネルギーは大きくなると予 測できる。

逆に，早強セメントを用いたコンクリートでは， 遷移帯の存在により, 界面強度が低下するので, 界 面強度線が低下して, 領域Bが拡大し, これに支配 される挙動となる。結果として破壊エネルギーは, ビーライト系に比較して，相対的に小さくなる。

このように，遷移帯の存在に影響される骨材の界 面強度の変化と, その影響の少ないモル夕ル部の強 度の両者を考えあわせることにより，実験的に観測 された材齢初期における，七メントの種類とコンク リートの破壊エネルギーの関係を説明することがで
きるのである。

\section{7. 結論}

本研究は，セメントの種類とコンクリートの破壊 力学特性值との関係を, 骨材界面とモルタルとの付 着特性に着目して，検討したものである．本研究に より得られた結論は以下の通りである。

(1) $\mathrm{C}_{3} \mathrm{~S}$ を多く含む早強セメントを用いたコンクリー トでは，骨材界面に遷移帯と呼ばれるポーラスで結 合力の弱い領域が存在する。このことを電子顕微鏡 観察によって確認した。 さらに，骨材とモルタルの 界面の付着強度が, $\mathrm{C}_{2} \mathrm{~S}$ を多く含むビーライト系セ メントを用いたコンクリートで高く，一方 $\mathrm{C}_{3} \mathrm{~S}$ を多 く含む早強セメントを用いたコンクリートで弱くな ることを割裂試験により実証した。

(2)ビーライト系セメントを用いたモルタルの材齢28 日での破壊エネルギーは，圧縮強度による補正を行 えば，早強セメントを用いたモルタルと同程度以上 となる。

(3)ビーライト系セメントを用いたコンクリートの破 壊エネルギーは，早強セメントを用いたコンクリー トに比べて，低強度時に特に大きくなる傾向があ る．材齢の進行に伴う強度発現にしたがって，圧縮 強度に伴う破壊エネルギーの増加はむしろ減少して いく傾向にあるが，ビーライト系セメントを用いた コンクリートでは長期の強度発現性に優れるので, 絶対的な破壊エネルギーは常に早強セメントを用い たコンクリートの破壊エネルギーを上回る傾向にあ る.

(4)ビーライト系セメントを用いたコンクリートで は，骨材界面に遷移帯がほとんど生成せず，した がって界面強度が大きくなる。このため, 骨材貫通 型の局所化したひび割れによる脆性的な破壊が起き やすいとも考えられるが，材齢初期の低強度時に は,このような脆性的な破壊よりもむしろモルタル 部そのものの破壊が支配的であって, 界面での付着 特性が強いほど，モル夕ル部の破壊が起こりやすく なる。このモルタル破壊の場合には，ひび割れが分 散し，コンクリート単位体積当たりに吸収される破 壞エネルギーが増加していくと考えられる.

(5)一方，早強セメントを用いたコンクリートでは， 遷移帯の存在により, 界面強度が低下し, 界面破壊 が先行すると考えられる。モル夕ル破壊に比較し て，ひび割れが界面に集中するので，吸収される破 壊エネルギーも減少していくこの考え方により， 材齢初期の低強度時に, 早強セメントを用いたコン クリートよりも，ビーライト系セメントを用いたコ ンクリートの方が，破壊エネルギーが大きくなるこ 


\section{とが説明できる。}

謝辞 : 本研究にあたり, 愛知工業大学工学部土木工 学科・森野奎二教授ならびに日本セメント（株）中 央研究所セメントコンクリート研究部・廣瀬 哲氏 から多大の協力を受けました。ここに記して梁甚の 謝意を表します。

\section{参考文献}

1) CEB: CEB-FIP Model Code 1990, Bulletin d'Information, No. 213/214, 437 pp., 1993.

2) 篠原保二, 安部武雄, 古村福次郎：ノッチ深さ, 載荷 速度, 骨材寸法, 水セメント比, 載荷法, 養生および 材令がコンクリート曲げ試験体の引張軟化特性に及ほ す影響, 日本建築学会構造系論文報告集, 第442号, pp. 13-22, 1992.12 .
3) 野村希晶, 三橋博三, 加藤敏史, 和泉正哲：コンク リートの内部構造と引張軟化特性, 材料, 第40巻, 第 456号, pp. 15-21，1991.9.

4) 松尾, 二羽, 岡本, 田邊: セメントの種類がコンク

リートの破壊力学特性值に及ほす影響, コンクリート 工学年次論文報告集, Vol. 17, No. 2, pp. 1311-1316 1995.6 .

5) 羽原俊祐：コンクリートの構造とその物性, わかりや すいセメント科学, セメント協会, pp. 78-104, 1993.3.

6) 内川 浩：セメントペーストと骨材の界面の構造・組 織がコンクリートの品質に及ぼす影響, コンクリート 工学, Vol. 33, No. 9, pp. 5-17, 1995.9.

7) 内田裕市, 六郷恵哲, 小柳 洽 : 曲げ試験に基づく引 張軟化曲線の推定と計測, 土木学会論文集, No. 426 , V-14, pp. 203-212, 1991.2.

(1995.10.30受付)

\title{
EXPERIMENTAL STUDY ON RELATIONSHIP BETWEEN TYPE OF CEMENTS AND FRACTURE PROPERTIES OF CONCRETE
}

\author{
Junichiro NIWA, Toyofumi MATSUO, Takahisa OKAMOTO and Tada-aki TANABE
}

The influence of type of cements on fracture properties of concrete has been investigated experimentally in relation to transition zone on aggregate surface. Even in early ages, concrete in which belite cement is used can exhibit relatively high fracture energy compared with its low strength developed. This behavior can be explained by the fact that transition zone rarely exists on aggregate surface in this concrete. On the other hand, concrete in which high-early strength cement is used shows smaller fracture energy because of the existence of transition zone. Based on the relationship between surface strength and fracture energy, this phenomenon has been explained qualitatively. 